\title{
Plasma concentrations of progesterone, oestrogens, testosterone and LH-like activity during the oestrous cycle of the camel (Camelus dromedarius)
}

\author{
A. M. Homeida, M. G. R. Khalil and A. A. M. Taha* \\ Departments of Veterinary Medicine, Pharmacology \& Toxicology and *Veterinary Anatomy, \\ University of Khartoum, P.O. Box 32, Khartoum North, Sudan
}

\begin{abstract}
Summary. Peripheral plasma concentrations of progesterone, total oestrogens and testosterone (measured by RIAs) and LH (monitored by the mouse Leydig cell bioassay) were measured in 8 female camels for a complete oestrous cycle $(23 \cdot 1 \pm 1 \cdot 2$ days). The absence of an LH surge and a low concentration of progesterone $(<1 \mathrm{ng} /$ $\mathrm{ml}$ ) during oestrus (5 days) and throughout the cycle indicated a failure of spontaneous ovulation and absence of a subsequent luteal phase in this species. High concentrations of testosterone and oestrogens indicated that the oestrous cycle in the camel is mostly follicular and that the increasing values of the two hormones during follicular development ( 5 days) is probably the stimulus to behavioural oestrus.
\end{abstract}

Keywords: camel; oestrous cycle; LH; progesterone; oestrogens; testosterone

\section{Introduction}

Very little is known about the reproductive endocrinology of the camel (Camelus dromedarius). Such information is essential to develop controlled breeding programmes because the camel has greater economic importance in the desert than do other domestic animals, and is also replacing cattle in arid and semi-arid zones. The lack of precise information about the oestrous cycle and the optimum time for the ovarian follicle to mature has led to failures of conception (Novoa, 1970; Musa \& Abusineina, 1978). Data available on the reproductive endocrinology of the camel are mainly obtained from morphological studies of the ovaries and uteri collected from the slaughter house (Tayeb, 1948; Shalash \& Nawito, 1964; Abdalla, 1965; Novoa, 1970; Arthur et al., 1986; ElWishy \& Ghoneim, 1986) or blood progesterone concentrations estimated during pregnancy (Elias et al., 1984). Camels are induced ovulators and therefore require coital contact for ovulation to be induced (Musa \& Abusineina, 1978; Elias et al., 1985; Marie \& Anouassi, 1987). The breeding pattern is characterized as seasonal polyoestrous (Shalash \& Nawito, 1964; Novoa, 1970). The main trigger of sexual receptivity for the camel is rainfall and subsequent availability of food.

This study was designed to investigate the reproductive hormone patterns during the oestrous cycle of camels kept under nomadic conditions.

\section{Materials and Methods}

Animals. Eight mature (4-5 years) female camels were kept under nomadic conditions in a herd of 38 camels during the breeding season (May/June). The animals were kept in a temporary pen surrounded by members of the herd. Oestrus was detected with the aid of a male camel which had free access to females and animals were considered to be in oestrus when they courted in a sitting position ready for mounting by the male. Mating was prevented. 
Rectal palpation. Rectal palpation was performed daily according to the method of Musa \& Abusineina (1978). The camel was restrained in the sitting position. The hand, lubricated with soft soap, was then passed into the rectum. The genital organs were normally found inside the pelvic cavity. The ovary was held in the hand after pulling the ovarian ligament posteriorly with the index finger. The surface of each ovary was examined and the findings were recorded.

Jugular blood $(10 \mathrm{ml})$ was obtained twice daily by venepuncture. All blood samples were collected into heparinized nylon syringes, stored in ice for a short period and centrifuged at $1500 \mathrm{~g}$ for $10 \mathrm{~min}$. Plasma samples were stored at $-30^{\circ} \mathrm{C}$ until analysis.

Hormone assays. All hormones except luteinizing hormone (LH) were measured by specific radioimmunoassay (RIA).

Plasma progesterone and testosterone were estimated by the RIA method previously described and validated by Homeida (1986a). The intra- and inter-assay coefficients of variation (CV) for progesterone were $4 \cdot 4 \%(n=20)$ and $12.3 \%(n=18)$, respectively, for a plasma sample of low progesterone concentration $(0.8 \mathrm{ng})$ and $4.2 \%(n=20)$ and $11.8 \%(n=20)$, respectively, for a plasma sample of high concentration $(5 \mathrm{ng})$. The sensitivity of the assay was $48 \mathrm{pg} /$ tube. Extraction efficiency was $85.7 \pm 4.9$ (s.d.) $\%$ and the results were corrected for extraction losses.

The intra-assay CV for testosterone was $12 \cdot 2 \%(n=12)$ for a plasma sample of low testosterone $(60 \mathrm{pg})$ and $12.7 \%(n=10)$ for a plasma sample of high testosterone concentration $(900 \mathrm{pg})$. Efficiency of radioactive hormone recovery was $73 \pm 1.7$ (s.d.) \% and values were corrected for extraction losses.

Total free oestrogens were estimated by the RIA method of Dobson \& Dean (1974) validated by Cooke \& Knifton (1980). The specificities and cross-reactions of the antisera used (gift from Dr H. Dobson) have been reported (Dobson \& Dean, 1974). Assaying a plasma sample of low hormone concentration (10 pg), the respective intra- and inter-assay CVs of variation were $12 \cdot 2(n=10)$ and $13.2 \%(n=8)$ for oestrone, $6 \cdot 6(n=11)$ and $8 \cdot 1 \%(n=7)$ for oestradiol-17 $\alpha$ and $7 \cdot 3(n=9)$ and $10 \cdot 2 \%(n=10)$ for oestradiol-17 $\beta$. Assaying a plasma sample of high hormone concentration $(100 \mathrm{pg})$, the respective intra- and inter-assay CVs were $6.3(n=8)$ and $12.2 \%(n=10)$ for oestrone, $4.9(n=11)$ and $7.3 \%(n=9)$ for oestradiol-17 $\alpha$ and $4.1(n=11)$ and $9.2 \%(n=10)$ for oestradiol-17 3 . The sensitivity of each assay was $4.2 \mathrm{pg}$ for oestrone, $7 \cdot 1 \mathrm{pg}$ for oestradiol-17 $\alpha$ and $5.0 \mathrm{pg}$ for oestradiol-17 $\beta$. Results for the oestrogens were corrected for recovery values which were $83 \cdot 5 \pm 4 \cdot 1 \%(n=25)$ for oestrone, $84 \cdot 2 \pm 3 \cdot 1 \%$ $(n=20)$ for oestradiol-17 $\alpha$ and $88.2 \pm 3.3 \%(n=24)$ for oestradiol-17\%

Bioassay of $L H$. A bioassay method using dispersed mouse Leydig cells (Ellinwood \& Resko, 1980; Henricks \& Poffenbarger, 1984) was used.

White mice (gift from the Centre for Tropical Veterinary Medicine, Edinburgh, U.K.) aged 6 weeks were housed

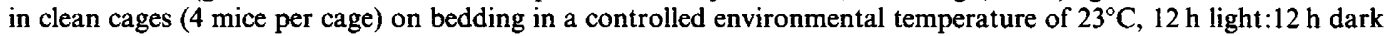
and relative humidity of $55 \%$, and were fed pelleted food made up of corn flour, meat and vegetables and were allowed free access to water. Mice were always killed at 08:00 h. Testes were quickly removed, decapsulated on ice and cut into small pieces. The pieces were placed into cold medium M-199 with Hank's salts, 25 mM-Hepes buffer (pH 7.35), L-glutamine and 0.2\% BSA (fraction V, Sigma, Poole, Dorset, U.K.) and were stirred with magnetic stirrer for $10 \mathrm{~min}$ at room temperature. Leydig cells were obtained by filtering the mixture through two layers of nylon mesh. The filtrate was preincubated for $60 \mathrm{~min}$ at $34^{\circ} \mathrm{C}$ in a shaking water bath. The cells were then centrifuged at $130 \mathrm{~g}$ for $15 \mathrm{~min}$ at $4^{\circ} \mathrm{C}$. Supernatant was decanted and cells were suspended in ice-cold M-199 containing no BSA at a final volume equivalent to $8 \mathrm{ml}$ per testis (about $67 \times 10^{3}$ total cells per $100 \mu \mathrm{l}$ ). Cell number was estimated by the Basic Blue method (Asher, 1973). Cell viability was determined by the trypan blue exclusion method (Phillips, 1973) and was about $83-85 \%$ in all assays. The cell suspension $(100 \mu \mathrm{l})$ was added to plastic tubes containing $100 \mu \mathrm{l} \mathrm{LH}$ standard (0.3-125 ng purified ovine LH: gift from Dr H. Dobson, University of Liverpool, U.K.) in M-199 containing 0.2\% BSA or an equivalent volume of unknown plasma sample. The tubes were incubated for $2 \mathrm{~h}$ at $37^{\circ} \mathrm{C}$ in a shaking water bath. The reaction was terminated by the addition of $1.8 \mathrm{ml}$ ice-cold $0.1 \mathrm{M}$-phosphate buffer $(\mathrm{pH} \mathrm{7.0)}$. The tubes were centrifuged at $1300 \mathrm{~g}$ for $15 \mathrm{~min}$ at $4^{\circ} \mathrm{C}$. The supernatant was decanted into tubes and prepared for testosterone determination as previously described.

The dose-response curves of the dilutions of LH standard $(6 \cdot 25,12 \cdot 5,25,50 \mathrm{ng})$ and camel pituitary extract (1.5, $3,6,12 \mu \mathrm{l})$ were parallel $(P>0.05)$ (Tallarida \& Murray, 1981; Homeida, 1986b). Oestradiol-17 $\beta(25 \mathrm{ng} / \mathrm{ml}), 5 \alpha-$ dihydrotestosterone $(20 \mathrm{ng} / \mathrm{ml})$, and progesterone $(20 \mathrm{ng} / \mathrm{ml})$ had no effect on testosterone production in the assay. Non-specific stimulation of the Leydig cells was checked by adding $100 \mu \mathrm{l} 1.5 \%$ BSA to M-199 medium and was found to be $<1 \%$. For 10 assays and intra-assay CVs were $9 \cdot 2 \%$ (500 pg added to camel plasma pool) and $10 \cdot 1 \%$ $(100 \mathrm{ng})$ and the inter-assay CVs were $14.3 \%(500 \mathrm{pg})$ and $12 \cdot 1 \%(100 \mathrm{ng})$. A dose of $150 \mathrm{pg} \mathrm{LH}$ produced significant $(P<0.01)$ testosterone release from Leydig cells compared to the blank and this was therefore considered to be the limit of sensitivity of the assay,

To demonstrate that the bioassay was able to measure LH in a dose-related manner in tissue containing trophic hormone, and that the camel pituitary has LH activity, a crude homogenate of anterior pituitary glands from female camels was collected from the slaughter house. The pituitary extract was prepared (Henricks \& Poffenbarger, 1984) by homogenizing $10 \mathrm{mg}$ anterior pituitary tissue with a motor-driven Teflon homogenizer in $0.5 \mathrm{M}$-phosphate buffer containing $0.2 \% \mathrm{BSA}$. The homogenate was centrifuged at $1900 \mathrm{~g}$ for $50 \mathrm{~min}$; the supernatant recovered was centrifuged at $20000 \mathrm{~g}$ for $30 \mathrm{~min}$. The precipitate was diluted $0.75 \times 10^{3}, 1.5 \times 10^{3}$ and $3 \times 10^{3}$ and $10 \mu \mathrm{l}$ of each dilution were tested in the Leydig cell bioassay system: the results were $0.6 \pm 0.1,1.3 \pm 0.1$ and $2.5 \pm 0.2 \mathrm{ng} / \mathrm{tube}$, respectively. The camel pituitary extract significantly $(P<0.001)$ increased testosterone production in the bioassay 
system. Examination of pituitary extract by disc gel electrophoresis in a $7 \cdot 5 \%$ gel at pH 8.3 (Ornstein, 1964) revealed a single, but diffuse, band at an $R_{\mathrm{f}}$ of 0.1 which was similar to patterns obtained from standard LH preparations from horses and sheep (Sigma, U.K.).

Statistical analyses. The results were compared by Student's $t$ test.

\section{Results}

A follicle $(0.5 \mathrm{~cm}$ ) was palpated (Table 1) in one of the ovaries 1-2 days before oestrus (Day 0$)$. The follicle steadily grew to reach its full size $(2-3 \mathrm{~cm})$ in $2-6$ days. The mature follicle maintained its size for 10-14 days and then regressed.

Table 1. Mean ( \pm s.d.) size of the largest follicle during an oestrous cycle of each of 8 camels

\begin{tabular}{cl}
\hline Days of oestrous cycle & $\begin{array}{c}\text { Follicle size } \\
(\mathrm{cm})\end{array}$ \\
\hline 0 & $1 \cdot 5 \pm 0 \cdot 2$ \\
2 & $2 \cdot \pm 0 \cdot 5$ \\
3 & $2 \cdot 5 \pm 0 \cdot 5$ \\
5 & $3 \pm 0 \cdot 5$ \\
7 & $3 \pm 0 \cdot 5$ \\
10 & $3 \pm 0 \cdot 5$ \\
15 & $2 \cdot 5 \pm 0 \cdot 5$ \\
20 & $0 \cdot 7 \pm 0 \cdot 2$ \\
23 & $0 \cdot 5 \pm 0 \cdot 1$ \\
\hline
\end{tabular}

Behavioural oestrus (starting from Day 0 ) was shown by 7 out of 8 camels for 4-6 days. During this period the females in oestrus chased and mounted other females; other symptoms included restlessness, a swollen vulva, hair around the vulva becoming stiff and the female accepting the male in a sitting position.

The mean $( \pm$ s.d.) length of the oestrous cycle was $23 \cdot 1 \pm 1 \cdot 2$ days.

The hormone concentrations measured are presented in Fig. 1. Peripheral plasma concentrations of progesterone remained $<1 \mathrm{ng} / \mathrm{ml}$ throughout the oestrous cycle. The concentrations of oestrogens and testosterone increased in parallel as the follicle grew in size. The level was $20 \mathrm{pg}$ oestrogens $/ \mathrm{ml}$ and $50 \mathrm{pg}$ testosterone $/ \mathrm{ml}$ when no follicle was palpable, increased steadily to reach a plateau level of $>80 \mathrm{pg}$ oestrogens $/ \mathrm{ml}$ and $1000 \mathrm{pg}$ testosterone $/ \mathrm{ml}$. Regression of the follicle was paralleled by low concentrations of oestrogens and testosterone. A high correlation coefficient $(r=0.97, P<0.001)$ between follicular size and concentrations of oestrogen and testosterone was found. The plateau level of the two hormones was maintained for 15 days and then decreased steadily as the follicle regressed.

LH concentrations remained very low $(<1 \mathrm{ng} / \mathrm{ml})$ and no peaks were observed throughout the oestrous cycle.

\section{Discussion}

The signs of oestrus in the camel reported in this study are similar to those previously described (Leese, 1927; Novoa, 1970; Musa \& Abusineina, 1978; Yagil \& Etzion, 1980; Elias et al., 1985). The length of the oestrous cycle in this study was 23-24 days. This consistency compared to previous reports of 2-4 weeks (Musa \& Abusineina, 1978; Joshi et al., 1978) may have been due to the study being conducted in the natural nomadic habitat of the camel. The duration of oestrus was about 5 days. 


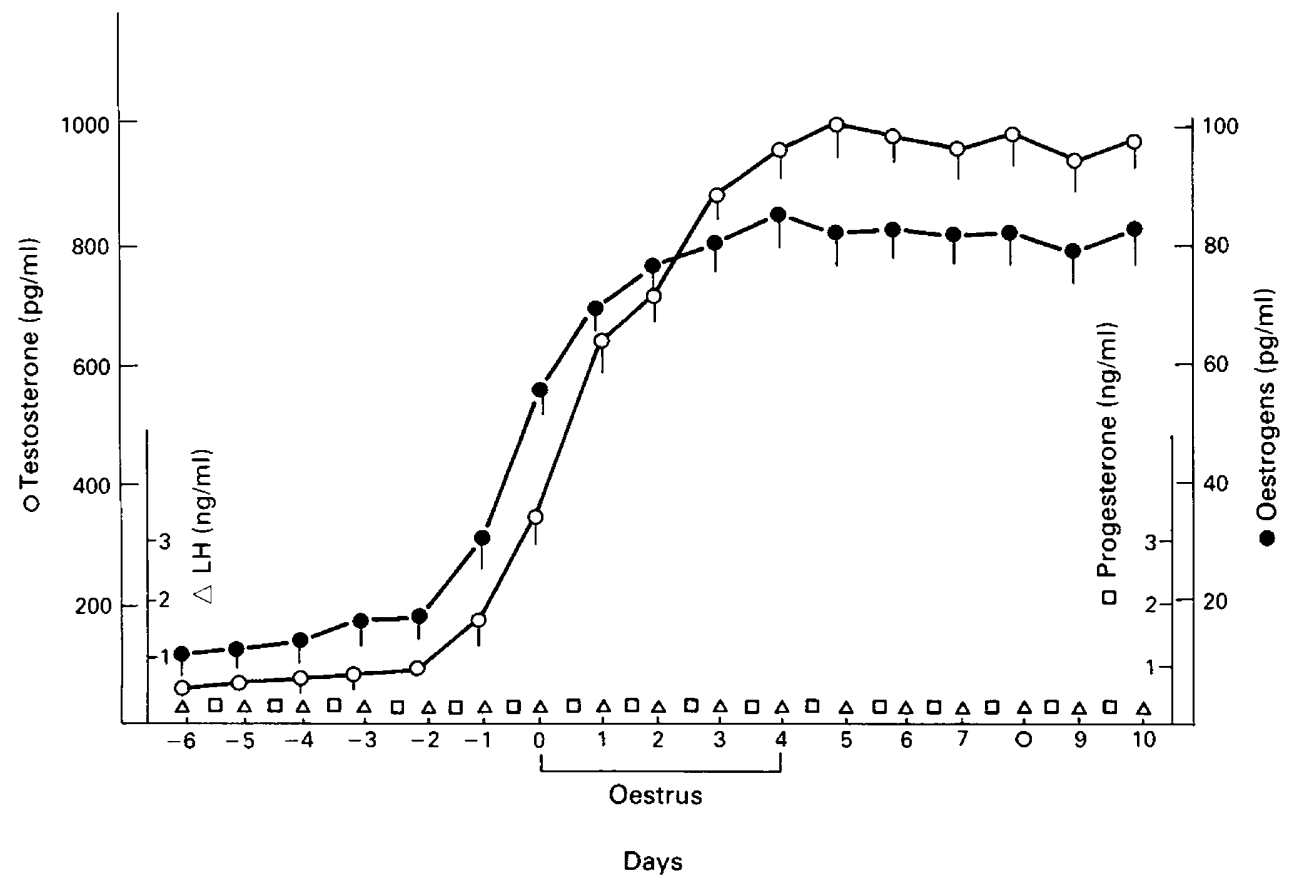

Fig. 1. Mean ( \pm s.e.m., 8 camels) peripheral plasma concentrations of progesterone $(\square)$, oestrogens $(\odot)$, testosterone $(O)$ and LH $(\triangle)$, during the oestrous cycle. The horizontal bar indicates oestrus.

The absence of an LH surge and low progesterone levels during the oestrous cycle are presumably related to the failure of ovulation and subsequent absence of a true luteal phase in this species, since well-developed corpora lutea only occur after successful mating (Shalash \& Nawito, 1964; Musa \& Abusineina, 1978; Arthur \& Rahim, 1982; Marie \& Anouassi, 1987). Oestrus can be induced in the camel by injections of PMSG (Elias et al., 1985) or oestradiol benzoate (Homeida et al., 1986), but ovulation did not occur in either study. However, Elias et al., 1985) reported that mating after PMSG resulted in pregnancy but abortion occurred as a result of inadequate luteal function.

Analysis of LH secretion during the cycle revealed no obvious changes that might explain control of growth and subsequent regression of follicles during the oestrous cycle. Basal release of LH may be related to follicular dynamics, but that relationship could not be examined without additional data as the overall pattern of LH secretion may not be revealed by samples taken only twice daily if LH is released in a pulsatile manner (Macmillan et al., 1984). However, folliculogenesis can continue in the absence of gonadotrophins in some species (Driancourt et al., 1987). Intra-ovarian factors may play a role in the regulation of follicular function (Hansel \& Convey, 1983).

The parallel increase in follicle size, oestrogens and testosterone concentration in this study suggested that both hormones are secreted by the follicle (Baird, 1983). Ovarian secretion of testosterone has also been reported for women, ewes, goats and cows (Short, 1962; McCracken et al., 1971; Abraham, 1974; Kanchev et al., 1976; Wise et al., 1982; Homeida, 1986a), although its physiological role is not clear. However, it has been suggested that ovarian androgens increase the rate of follicular atresia (Louvet et al., 1975; Ware, 1982).

In farm animals, a decline in progesterone concentration is coupled with a rise in oestrogens and the two changes may be responsible for induction of behavioural oestrus (Robertson, 1969; 
McCracken et al., 1971; Pant et al., 1977; Homeida \& Cooke 1982). However, Morin \& Feder (1973) and Sodersten \& Hansen (1977) have demonstrated that progesterone, at least in the rat and guinea-pig, is not a prerequisite for induction of oestrus in contrast to oestrogens. It seems likely that in the camel a rise (or change) in oestrogens and testosterone concentration rather than a plateau level of the two hormones may be responsible for induction of behavioural oestrus. Exogenously administered testosterone (Young, 1961; Katz et al., 1980; Homeida \& Cooke, 1984) or oestrogen (Boyer \& McDonald, 1973; Jones \& Knifton, 1982; Homeida et al., 1986) can induce oestrus in animals. Such effects may be attributed to the aromatization of testosterone to the oestrogen which is required for expression of oestrus (Homeida, 1986a). As oestrogens and testosterone started to increase and reached a plateau level in 4-5 days (time of follicular maturation and oestrus) (Musa \& Abusineina, 1978), it is suggested that mating in this species should take place towards the end of oestrus when the follicle matures and mating will result in conception. However, work is now in progress to elucidate the optimum time for conception in this species.

We thank the International Atomic Energy Agency (Vienna) for financial support; and Professor H.-O. Hoppen (Chemisches Institut, Hannover, F.R.G.) for help with the Leydig cell bioassay. M.G.R.K. is a masters student supported by the Higher Education Division, Sudan.

\section{References}

Abdalla, O. (1965) Anatomical study of the female genital system of the one-humped camel (Camelus dromedarius). 1. The ovaries. Sud. J. vet. Sci. anim. Husb. 6, 41-52.

Abraham, G.E. (1974) Ovarian and adrenal contribution to peripheral androgens during menstrual cycle. $J$. clin. Endocr. Metab. 39, 340-347.

Asher, M. (1973) Hemocytometer counting. In Tissue Culture: Methods and Application, p. 395. Eds P. F. Kruse, Jr \& M. K. Patterson, Jr. Academic Press, New York.

Arthur, G.H. \& Rahim, A.T. (1982) Aspect of reproduction in the female camel (Camelus dromedarius) in Saudi Arabia. Vet. Med. Review 1, 83-88.

Arthur, G.H., Rahim, A.T. \& Hindi, A.S. (1986) Reproduction and genital disease of the camel. In The Camel in Health and Disease, pp. 111-120. Ed. A. J. Higgins. Bailliere Tindall, London.

Baird, D.T. (1983) Factors regulating the growth of the preovulatory follicle in the sheep and human. $J$. Reprod. Fert. 69, 343-352.

Boyer, C. \& McDonald, P. (1973) Hormonal control of sexual behaviour in female rabbits. Adv. Reprod. Physiol. 6, 195-214.

Cooke, R.G. \& Knifton, A. (1980) The effect of intraaortic prostaglandin F. $2 \alpha$ on uterine motility in pregnant goats. J. Reprod. Fert. 59, 347-350.

Dobson, H. \& Dean, P.D.G. (1974) Radioimmunoassay of oestrone, oestradiol-17 $\alpha$ and oestradiol-17 $\beta$ in bovine plasma during the oestrous cycle and last stages of pregnancy. J. Endocr. 61, 479-486.

Driancourt, M.A., Fry, R.C., Clarke, I.J. \& Cahill, L.P. (1987) Follicular growth and regression during the 8 days after hypophysectomy in sheep. J. Reprod. Fert. 79, 635-641.

Elias, E., Bedrak, E. \& Yagil, R. (1984) Peripheral blood levels of progesterone in female camels during various reproductive stages. Gen. comp. Endocr. 53, 235-240.
Elias, E., Bedrak, E. \& Cohen, D. (1985) Induction of oestrus in the camel (Camelus dromedarius) during seasonal anoestrus. J. Reprod. Fert. 74, 519-525.

Ellinwood, W.E. \& Resko, J.A. (1980) Sex differences in biologically active and immunoreactive gonadotropins in the fetal circulation of rhesus monkeys. Endocrinology 107, 902-907.

ElWishy, A.B. \& Ghoneim, I.M. (1986) Breeding activity of the camel (Camelus dromedarius). Anim. Reprod. Sci. 11, 75-77.

Hansel, W. \& Convey, E. (1983) Physiology of the estrous cycle. J. Anim. Sci. 57, Suppl. Z, 404-424.

Henricks, D.M. \& Poffenbarger, J.I. (1984) Mouse Leydig cell bioassay shows lack of LH in the bovine preimplantation conceptus. J. Reprod. Fert. 71, 419-426.

Homeida, A.M. (1986a) Use of spironolactone to investigate the role of testosterone secretion during luteolysis in the goat. J. Reprod. Fert. 76, 153-157.

Homeida, A.M. (1986b) Evidence for the presence of oxytocin in the corpus luteum of the goat. $B r . J$. Pharmac. 87, 673-676.

Homeida, A.M. \& Cooke, R.G. (1982) Peripheral plasma concentration of 13,14-dihydro-15-keto-prostaglan$\operatorname{din} \mathrm{F}_{2 \alpha}$ and progesterone around luteolysis and during early pregnancy in the goat. Prostaglandins 24, 313-321.

Homeida, A.M. \& Cooke, R.G. (1984) Plasma concentration of testosterone and $5 a$-dihydrotestosterone around luteolysis in goats and their behavioural effects after ovariectomy. J. Steroid Biochem. 20, 1357-1359.

Homeida, A.M., Musa, B.E. \& Mohammed, F.H.A. (1986) Induction of oestrus in camels by the use of oestradiol benzoate. Small Ruminant and Camel Group (ILCA) 12, 21-24.

Jones, D. E. \& Knifton, A. (1982) Oestrogen therapy without stilbenes. Vet. Rec. 110, 441-443. 
Joshi, C.K., Vyas, K.K. \& Pareek, P.K. (1978) Studies on oestrous cycle in bactrian She-camels. Indian J. Anim. Sci. 48, 141-145.

Kanchev, L.N., Dobson, H., Ward, W.R. \& Fitzpatrick, R.J. (1976) Concentration of steroids in bovine peripheral plasma during the oestrous cycle and effects of betamethasone treatment. J. Reprod. Fert. 48, 341-345.

Katz, L.S., Oltenacu, E.A.B. \& Foote, R.H. (1980) The behavioral responses in ovariectomized cattle to either estradiol, testosterone, androstenedione or dihydrotestosterone. Horm. Behav. 14, 224-235.

Leese, A. (1927) A Treatise on the Humped Camel. Haynes \& Sons, Starford.

Louvet, J.P., Harman, S.M., Schreiber, J.R. \& Ross, G.T. (1975) Evidence for a role of androgens in follicular maturation. Endocrinology 97, 366-372.

Macmillan, K.L., Fielden, E.D., McNatty, K.P. \& Henderson, H.V. (1984) LH concentrations in two cattle with XY gonadal dysgenesis. J. Reprod. Fert. 71, 525-531.

Marie, A. \& Anouassi, A. (1987) Induction of luteal activity and progesterone secretion in the nonpregnant one-humped camel (Camelus dromedarius). $J$. Reprod. Fert. 80, 183-192.

McCracken, J.A., Baird, D.T. \& Goding, J.R. (1971) Factors affecting the secretion of steroids from the transplanted ovary in sheep. Recent Prog. Horm. Res. 27, 537-647.

Morin, L.P. \& Feder, H.H. (1973) Multiple progesterone injections and the duration of oestrus in ovariectomized guinea pig. Physiol. Behav. 11, 861-865.

Musa, B.E. \& Abusineina, A.A. (1978) The oestrous cycle of the camel (Camelus dromedarius). Vet. Rec. 103, 556-557.

Novoa, C. (1970) Reproduction in Camelidae. J. Reprod. Fert. 22, 3-20.

Ornstein, L. (1964) Disc electrophoresis-1. Ann. N.Y. Acad. Sci. 121, 321-349.

Pant, H.C., Hopkinson, C.R.N. \& Fitzpatrick, R.J. (1977) Concentration of oestradiol, progesterone, luteinizing hormone and follicle stimulating hormone in the jugular venous plasma of ewes during the oestrous cycle. J. Endocr. 73, 247-255.

Phillips, H.J. (1973) Dye exclusion tests for cell viability. In Tissue culture: Methods and Applications, p. 406. Eds P. F. Kruse, Jr \& M. K. Petterson, Jr. Academic Press, New York.

Robertson, H.A. (1969) The endogenous control of estrus and ovulation in sheep, cattle and swine. Vitams Horm. 27, 91-130.

Shalash, M.R. \& Nawito, M. (1964) Some reproductive aspects in the female camel. Proc. 5th Int. Congr. Anim. Reprod. \& A.I., Trento, pp. 263-273.

Short, R.V. (1962) Steroids present in the follicular fluid of the cow. J. Endocr. 23, 401-411.

Sodersten, P. \& Hansen, S. (1977) Effect of oestradiol and progesterone on the induction and duration of sexual receptivity in cyclic female rats. J. Endocr. 74, 477-485.

Tallarida, R.J. \& Murray, R.B. (Eds) (1988) Mannual Pharmacologic Calculations, p. 11. Springer-Verlag, New York.

Tayeb, M.A.F. (1948) Studies on the anatomy of the ovary and corpus luteum of the camel. Br. vet.J. 104, 179-186.

Ware, V.C. (1982) The role of androgens in follicular development in the ovary. 1. A quantitative analysis of oocyte ovulation. J. exp. Zool. 222, 55-167.

Wise, T.H., Caton, D., Thatcher, W.W., Ramilehrer, A. \& Fields, M.J. (1982) Androstenedione, dehydroepiandrosterone and testosterone in ovarian vein plasma and androstenedione in peripheral arterial plasma during the bovine oestrous cycle. J. Reprod. Fert. 66, 513-518.

Yagil, R. \& Etzion, Z. (1980) Hormonal and behavioural patterns in the male camel (Camelus dromedarius). $J$. Reprod. Fert. 58, 61-65.

Young, W.C. (1961) Sex and Internal Secretions, p. 1196. Ed. W. C. Young. Williams and Wilkins, Baltimore.

Received 1 September 1987 